Egyptian Journal of Aquatic Biology \& Fisheries

Zoology Department, Faculty of Science,

Ain Shams University, Cairo, Egypt.

ISSN $1110-6131$

Vol. 22(3): 183- 192 (2018)

www.ejabf.journals.ekb.eg

\title{
Growth performance and biochemical blood parameters of Nile tilapia, Oreochromis niloticus, and thinlip mullet, Liza ramada, fed a diet supplemented with lemon (Citrus aurantifolia) peel in a polyculture system
}

\author{
Mohamed M. Toutou ${ }^{1}$, Ali A. Soliman ${ }^{1}$, Mohamed A. Elokaby ${ }^{2}$, Ragaa A. Ahmed ${ }^{3}$ and \\ Baghdady. E. S ${ }^{3}$ \\ 1- Fish Nutrition Laboratory, Aquaculture Division, National Institute of Oceanography and \\ Fisheries (NIOF), Egypt. \\ 2- Fish Rearing Laboratory, Aquaculture Division, (NIOF), Egypt. \\ 3- Department of Aquaculture, Faculty of Fish \& Fisheries Technology, Aswan University. \\ *Correspondence Author :mtoutou50@yahoo.com
}

\section{ARTICLE INFO}

Article History:

Received: Oct. 23, 2018

Accepted: Dec, 10, 2018

Online: Dec. 30, 2018

\section{Keywords:}

Liza ramada

Thinlip mullet

Oreochromis niloticus

Nile tilapia

Citrus aurantifolia

Growth performance

\section{ABSTRACT}

The objective of the current study was to evaluate the growth performance, survival, feed utilization, whole body composition and biochemical blood parameters of Nile tilapia, Oreochromis niloticus and thinlip mullet, Liza ramada, fed diets supplemented with four levels of lemon peel $(0,0.5,1$ and $2 \%$ ) in a polyculture system. The fish were stocked in $2 \times 5 \times 1 \mathrm{~m}$ concrete tanks at a density of 40 Nile tilapia (0.6 g) and 10 thinlip mullet (3.3 g) fingerlings per tank and were fed a pelleted diet ( 25\% Crude protein), twice daily for 77 days. Treatment with $2 \%$ lemon peel had significant positive effects on growth, feed utilization and total biomass of Nile tilapia, whereas $0.5 \%$ lemon peel was optimal for thinlip mullet. The blood parameter results showed thatNile tilapia fed $2 \%$ dietary lemon peel had the lowest triglyceride, amylase and glucose levels. In contrast, thinlip mullet fed $0.5 \%$ dietary lemon peel had the highest levels of amylase and glucose compared with the other groups.

\section{INTRODUCTION}

Aquaculture requires optimization of nutrition to efficiently raise fish for the purpose of food production. Fish nutrition is the study of nutrients and energy sources essential for fish health, growth and reproduction (Hixson, 2014). In recent years, aquaculture has been growing at an annual rate of $3.2 \%$. This is mostly attributed to developments in fish feed manufacture, which is the biggest cost factor, and the use of more productive aquaculture systems (FAO, 2016). However, this production is obstructed by unexpected mortalities that may be owing to negative interactions between pathogenic bacteria and fish. To face this problem, farmers often use antibiotic compounds to cure bacterial diseases (Cabello, 2006).However, the use of antibiotics leads to antibiotic resistance in bacteria as well as residues in fish fillets (Esiobuet al., 2002). Due to the side effects as well as the resistance that pathogens build against antibiotics, many attention has recently been spend to extracts and biologically active compounds secluded from plant species. Using of plant extracts, and other alternative forms of medicinal treatments, is widely popular (Cowan, 1999). 
In recent years, immune-stimulant plants or their by-products have been used in aquaculture feed as an antibiotics alternative. The most important advantages of natural products are that they neither cause any residue problems nor have any negative effects on fish health or humans and the environment (Baba et al., 2016). A number of agro-industrial by-products or wastes such as citrus pulp, citrus meal, citrus seed meal, citrus molasses and citrus peels are generated from fresh citrus after the main products of interest have been removed or extracted during processing or after peeling for direct human consumption, especially in developing countries (Oluremiet al., 2007). The residue left after extraction of the juice is called citrus pulp (50-70\% of the fruit by weight). Citrus pulp contains $60-65 \%$ peel, $30-35 \%$ internal tissues and up to $10 \%$ seeds (Crawshaw, 2004). Many studies illustrated lemon as an important health-promoting fruit rich in phenolic compounds as well as vitamins, minerals, dietary fibre, essential oils and carotenoids. Lemons contain vitamin C, also known as ascorbic acid (Njokuet al., 2011). Vitamin C has antioxidant and therapeutic properties in many organisms. Among the vitamins essential for fish growth, vitamin $\mathrm{C}$ has been found to be an important element for the growth, reproduction and physiology of fish. This is because, unlike other animals, fish lack the enzyme gulonolactone oxidase necessary in the last step in the biosynthesis of ascorbic acid (Merchie, et al., 1997). Growth performance, survival, haematological, biochemical and immunological variables are among the most significant physiological indicators of fish health (Campbell, 2004). Thus, the objectives of the present study were to evaluate the effects of dietary lemon peel on the growth and biochemical blood parameters of polycultured Nile tilapia and thinlip mullet.

\section{MATERIALS AND METHODS}

\section{Fish and experimental design:}

This experiment was conducted at the Fish Nutrition Laboratory, Baltim Research Station, National Institute of Oceanography and Fisheries (NIOF), Egypt, during summer 2018. Nile tilapia and thinlip mullet fingerlings were purchased from a private fish farm in Kafr El-Sheikh Governorate, Egypt. After acclimation in a concrete tank $(5 \times 10 \times 1 \mathrm{~m})$ for two weeks, forty Nile tilapia and ten thinlip mullet fish with an average weight of $(0.6 \pm 0.1$ and $3.3 \pm 0.4 \mathrm{~g}$, respectively) were randomly stocked in 12 concrete tanks $(2 \times 5 \times 1 \mathrm{~m})$, representing four treatments with three replicates each. The experimental tanks were cleaned and supplied with fresh underground water and aeration. Water quality parameters, including temperature, $\mathrm{pH}$ (Jenway Ltd., Model 350 pH meter) and dissolved oxygen (Jenway Ltd., Model 970dissolved oxygen meter), were measured weekly. Throughout the experimental period, the ambient water temperature, dissolved oxygen and $\mathrm{pH}$ were $24.0 \pm 2.0^{\circ} \mathrm{C}$, $6.0 \pm 2.0 \mathrm{mg} / \mathrm{l}$, and $7.9 \pm 0.2$, respectively. Fish were fed the experimental diets $(5 \%$ to 3\%) twice per day at 09.00 and 14.00 h, 6 days per week for 11 weeks. A flowthrough system was used in this study with $10 \%$ daily water exchange.

\section{Experimental diets and feeding regime}

Isonitrogenous ( $25 \%$ crude protein), isocaloric ( $\sim 42 \mathrm{Kcal} / 100$ g gross energy, GE) experimental diets were prepared as shown in Table (1). The ingredients were blended with additional water to make a paste of each diet. The pastes were pelleted into an appropriate size suitable for the experimental fish size. The feed was dried in an oven that was thermostatically regulated at $60^{\circ} \mathrm{C}$ for 24 hours and was then stored in plastic bags at $-20^{\circ} \mathrm{C}$ until use. Four experimental diets were formulated $(\mathrm{C}, \mathrm{L} 1$, L2 and L3); C was considered the control diet. Lemon peel (L1, L2 and L3) was 
added $(0.5,1,2 \%)$, and the formulated feed was prepared in the fish nutrition laboratory (NIOF) The proximate chemical analyses of the formulated feed (on a dry matter (DM) basis) are presented in Table (1). During the experiment, the total quantity of feed consumed by fish in each tank was determined, and the feed intake of each individual fish was calculated accordingly.

Table 1: The composition and chemical analysis (\% on dry matter basis) of the experimental diets.

\begin{tabular}{|c|c|c|c|c|}
\hline \multirow{2}{*}{ Ingredients } & \multicolumn{3}{|c|}{ Composition of experimental diets/kg. } \\
\cline { 2 - 4 } & Control & L1 & L2 & L3 \\
\hline Fish meal (65\% CP) & 100 & 100 & 100 & 100 \\
\hline Soybean meal (44\% CP) & 220 & 220 & 220 & 220 \\
\hline Wheat bran & 300 & 300 & 300 & 300 \\
\hline Sesame meal & 100 & 100 & 100 & 100 \\
\hline Yellow corn & 120 & 120 & 120 & 120 \\
\hline Wheat flour & 60 & 55 & 50 & 40 \\
\hline Premix & 20 & 20 & 20 & 20 \\
\hline Fish oil & 30 & 30 & 30 & 30 \\
\hline Sunflower oil & 30 & 30 & 30 & 30 \\
\hline Dicalcium phosphate & 20 & 20 & 20 & 20 \\
\hline Lemon peel & 0 & 5 & 10 & 20 \\
\hline Total & 1000 & 1000 & 1000 & 1000 \\
\hline Dry matter (DM) & \multicolumn{4}{|c|}{ Chemical composition \% } \\
\hline Crude protein (CP) & 93.8 & 92.9 & 91.4 & 90.1 \\
\hline Ether extract & 25.3 & 25.1 & 25.2 & 24.9 \\
\hline Ash & 11.3 & 11.4 & 11.5 & 11.6 \\
\hline Crude fibre & 12.0 & 12.1 & 12.2 & 12.2 \\
\hline Nitrogen-free extract (NFE) ${ }^{2}$ & 4.3 & 4.3 & 4.5 & 4.6 \\
\hline Gross energy (kcal/100 g DM ${ }^{3}$ & 442.9 & 442.8 & 442.2 & 492.0 \\
\hline
\end{tabular}

${ }^{1}$ Premix Composition: - Each 1 kg contains Vit. A (400000 i.u.), Vit.D3 (100000 i.u.), Vit. E (230 mg), Vit. K3 (165 mg), Vit.B1 (300 mg), Vit.B2 (80 mg), Vit.B6 (200 mg), Vit.B12 (1 mg), Vit. C (650 mg), niacin (1000 mg), methionine (3000 mg), choline chloride (10000 mg), folic acid (100 mg), biotin (2 mg), pantothenic acid (220 $\mathrm{mg}$ ), magnesium sulphate (1000 mg), copper sulphate (1000 mg), iron sulphate (330 mg), zinc sulphate (600 mg), cobalt sulphate (100 mg), and calcium carbonate, up to $1000 \mathrm{mg}$.

${ }^{2} \mathrm{NFE}=100-[\%$ Ash $+\%$ lipid $+\%$ protein $+\%$ Fibre $]$

${ }^{3}$ Gross energy (GE) was calculated as 5.64, 9.44 and $4.11 \mathrm{kcal} / 100 \mathrm{~g}$ for protein, lipids and NFE, respectively (NRC, 1993).

\section{Growth performance and feed utilization efficiency:}

At the end of the experiment, fish were harvested, counted, and weighed. The growth performance and feed utilization parameters were determined as follows:

Weight gain (WG; g) = FW - IW

Specific growth rate (SGR; \%/fish/day) $=100 *[(\mathrm{LnFW})-(\mathrm{LnIW})] /$ experimental days, where FW: final fish weight (g); IW: initial fish weight (g)

Condition factor (K value) $=100 *$ [Fish weight, g/fish length $\left.{ }^{3}, \mathrm{~cm}\right]$

Fish survival $(\%)=100 *$ [Final number of fish/initial number of fish]

Daily Feeding Rate (\%/fish weight/day) $=100 *$ [FI/FW],

where FI = total actual feed intake (g) based on fresh matter (FM) or dry matter (DM); FW = average weight of fish (g)

Feed conversion ratio (FCR) based on DM = feed intake (g) as dry weight/weight gain (g);

Feed conversion ratio (FCR) based on FM = feed intake (g) as fresh matter/weight gain $(\mathrm{g})$; Protein efficiency ratio $(\mathrm{PER})=$ weight gain $(\mathrm{g}) /$ protein intake $(\mathrm{g})$; Protein productive value (PPV; \%) $=100 *$ [protein gain (g)/protein intake (g)]. 


\section{Proximate chemical analyses of feed and fish}

At the beginning of the experiment, a sample of the tested fish (approximately 30 fish) was randomly collected and preserved for initial body chemical composition. At the end of the experiment, 15 fish from each treatment were sampled for determination of proximate chemical composition. Specimens of the tested feeds and fish samples were subjected to proximate chemical analyses to measure the moisture, crude protein (CP), crude lipid, crude fibre, and ash contents according to AOAC (2000).

\section{Serum biochemistry:}

Blood samples were collected, placed in centrifuge tubes and allowed to clot at room temperature. Serum was then separated by centrifugation at $3000 \mathrm{rpm}$ for 10 minutes. The serum was kept at $-20^{\circ} \mathrm{C}$ until analysis of cholesterol, triglycerides creatinine, urea, lipase and amylase.Creatinine and urea $(\mathrm{mg} / \mathrm{dl})$ were quantitatively estimated according to the method of Henry (1964). Serum glucose (mg/dl) was quantitatively estimated by enzymatic colorimetric methods described by Trinder (1969), and serum cholesterol (mg/dl) was estimated by enzymatic colorimetric methods described by Thomas (1992). Serum triglycerides (mg/dl) were estimated according to the method of Friedewald et al. (1972). Lipase and amylase (U/l) were measured calorimetrically using commercial kits purchased from Bio-diagnostic Co. (Alexandria, Egypt).

\section{Statistical analysis:}

Data collected on the investigated traits (growth performance, feed utilization, biochemical and blood serum analyses) were analysed with one-way analysis of variance (ANOVA) using the SPSS version 16 statistical package to evaluate the di

treatment were assessed using Duncan's multiple range test at the $\mathrm{P} \leq 0.05$ level. SPSS (1997).

\section{RESULTS}

The growth performance parameters of Nile tilapia and thinlip mullet are presented in Table 2. A significant increase $(\mathrm{P} \leq 0.05)$ in the final body weight $(\mathrm{FW})$, weight gain (WG) and specific growth rate (SGR) was observed in response to the diets supplemented with 0.5, 1.0, and $2 \%$ lemon peel (Nile tilapia) and $0.5 \%$ lemon peel (thinlip mullet) compared to the control.

Table 2: Growth variables and indices of Nile tilapia and thinlip mullet at the end of the 77-day feeding trial.

\begin{tabular}{|c|c|c|c|c|}
\hline & \multicolumn{4}{|c|}{ Nile tilapia } \\
\cline { 2 - 5 } & $\mathbf{C}$ & L1 & L2 & L3 \\
\hline Initial wt. & $0.73 \pm 0.01$ & $0.73 \pm 0.01$ & $0.72 \pm 0.01$ & $0.73 \pm 0.01$ \\
\hline Final wt. & $14.54 \pm 0.99^{\mathrm{c}}$ & $19.98 \pm 0.39^{\mathrm{b}}$ & $19.75 \pm 0.59^{\mathrm{b}}$ & $22.96 \pm 0.09^{\mathrm{a}}$ \\
\hline Weight gain & $13.81 \pm 0.99^{\mathrm{c}}$ & $19.25 \pm 0.39^{\mathrm{b}}$ & $19.04 \pm 0.58^{\mathrm{b}}$ & $22.24 \pm 0.08^{\mathrm{a}}$ \\
\hline SGR & $3.88 \pm 0.09^{\mathrm{c}}$ & $4.31 \pm 0.02^{\mathrm{b}}$ & $4.31 \pm 0.04^{\mathrm{b}}$ & $4.49 \pm 0.01^{\mathrm{a}}$ \\
\hline Survival & $77.50 \pm 1.44$ & $76.67 \pm 0.83$ & $72.50 \pm 5.20$ & $74.17 \pm 1.67$ \\
\hline & \multicolumn{4}{|c|}{ Thinlip mullet } \\
\cline { 2 - 5 } & $\mathbf{C}$ & L1 & L2 & L3 \\
\hline Initial wt. & $3.53 \pm 0.08$ & $3.45 \pm 0.16$ & $3.45 \pm 0.06$ & $3.50 \pm 0.08$ \\
\hline Final wt. & $15.16 \pm 0.47^{\mathrm{b}}$ & $19.16 \pm 0.93^{\mathrm{a}}$ & $15.77 \pm 0.23^{\mathrm{b}}$ & $14.56 \pm 0.15^{\mathrm{b}}$ \\
\hline Weight gain & $11.63 \pm 0.44^{\mathrm{b}}$ & $15.71 \pm 0.78^{\mathrm{a}}$ & $12.32 \pm 0.26^{\mathrm{b}}$ & $11.06 \pm 0.23^{\mathrm{b}}$ \\
\hline SGR & $1.89 \pm 0.04 \mathrm{~b}^{\mathrm{c}}$ & $2.22 \pm 0.01^{\mathrm{a}}$ & $1.97 \pm 0.04^{\mathrm{b}}$ & $1.85 \pm 0.04^{\mathrm{c}}$ \\
\hline Survival & $76.67 \pm 6.67^{\mathrm{b}}$ & $93.33 \pm 3.33^{\mathrm{a}}$ & $90.00 \pm 5.77^{\mathrm{a}}$ & $83.33 \pm 6.67^{\mathrm{ab}}$ \\
\hline
\end{tabular}


The highest final body weight, weight gain, and SGR were recorded in tilapia fed the $2 \%$ dietary lemon peel. The Nile tilapia survival results showed that there were no significant differences between the lemon peel treatments and the control treatment. In contrast, the thinlip mullet survival results differed significantly between treatments, with the highest value observed in the L1 treatment followed by L2, L3 and the control, which had the lowest value. Also, the highest final body weight, weight gain and SGR were recorded in the fish fed on $0.5 \%$ lemon peel.

Table 3: Total growth and total biomass indices of the polyculture (Nile tilapia and thinlip mullet) at the end of the 77-day feeding trial.

\begin{tabular}{|c|c|c|c|c|}
\hline & C & L1 & L2 & L3 \\
\hline Initial wt. & $1.29 \pm 0.02$ & $1.27 \pm 0.03$ & $1.26 \pm 0.02$ & $1.28 \pm 0.02$ \\
\hline Final wt. & $14.69 \pm 0.76^{\mathrm{c}}$ & $19.76 \pm 0.25^{\mathrm{ab}}$ & $18.79 \pm 0.34^{\mathrm{b}}$ & $20.91 \pm 0.15^{\mathrm{a}}$ \\
\hline weight gain & $13.40 \pm 0.78^{\mathrm{c}}$ & $18.49 \pm 0.24^{\mathrm{ab}}$ & $17.52 \pm 0.33^{\mathrm{b}}$ & $19.63 \pm 0.13^{\mathrm{a}}$ \\
\hline SGR & $3.16 \pm 0.08^{\mathrm{b}}$ & $3.57 \pm 0.02^{\mathrm{a}}$ & $3.51 \pm 0.02^{\mathrm{a}}$ & $3.63 \pm 0.01^{\mathrm{a}}$ \\
\hline Feed intake & $32.37 \pm 0.96^{\mathrm{b}}$ & $34.87 \pm 0.47^{\mathrm{a}}$ & $33.15 \pm 2.09^{\mathrm{a}}$ & $36.85 \pm 1.25^{\mathrm{a}}$ \\
\hline FCR & $2.42 \pm 0.07^{\mathrm{b}}$ & $1.88 \pm 0.02^{\mathrm{a}}$ & $1.89 \pm 0.08^{\mathrm{a}}$ & $1.88 \pm 0.05^{\mathrm{a}}$ \\
\hline PER & $1.65 \pm 0.04^{\mathrm{b}}$ & $2.12 \pm 0.03^{\mathrm{a}}$ & $2.14 \pm 0.10^{\mathrm{a}}$ & $2.18 \pm 0.06^{\mathrm{a}}$ \\
\hline
\end{tabular}

The SGR and PER values of whole polyculture species fed diets supplemented with $0.5,1$, and $2 \%$ lemon peel were significantly ( $\mathrm{P} \leq 0.5)$ higher than those of polyculture species fed the control diet. However, the feed conversion ratio (FCR) measured in fish fed diets supplemented with $0.5,1$, and $2 \%$ lemon peel was significantly $(\mathrm{P} \leq 0.5)$ lower than that in fish fed the control diet.

The effects of dietary lemon peel on the biochemical composition of Nile tilapia are presented in Table (4), which shows that no significant differences were observed for moisture content. An increase in the lemon peel level to $0.5 \%$ and $1 \%$ induced a significant reduction in the crude protein (CP) content of the fish whole body compared to the control. At the same time, non-significant different was recorded in the value of $\mathrm{CP}$ of the fish fed on $2 \%$ lumen peel compared to the control.

Table 4: Biochemical composition of Nile tilapia and thinlip mullet at the end of the feeding trial (dry matter weight basis).

\begin{tabular}{|c|c|c|c|c|c|}
\hline & \multicolumn{5}{|c|}{ Nile tilapia } \\
\cline { 2 - 6 } & Initial & C & L1 & L2 & L3 \\
\hline Moisture & $78.83 \pm 0.26$ & $75.30 \pm 0.55^{\mathrm{a}}$ & $74.43 \pm 0.42^{\mathrm{a}}$ & $74.20 \pm 1.17^{\mathrm{a}}$ & $75.87 \pm 0.50^{\mathrm{a}}$ \\
\hline CP & $58.80 \pm 0.36$ & $68.07 \pm 0.30^{\mathrm{a}}$ & $63.17 \pm 0.09^{\mathrm{b}}$ & $63.67 \pm 0.52^{\mathrm{b}}$ & $68.30 \pm 0.15^{\mathrm{a}}$ \\
\hline EE & $11.27 \pm 0.18$ & $16.87 \pm 0.35^{\mathrm{b}}$ & $23.20 \pm 0.10^{\mathrm{a}}$ & $22.23 \pm 0.59^{\mathrm{a}}$ & $12.50 \pm 0.10^{\mathrm{c}}$ \\
\hline Ash & $29.50 \pm 0.23$ & $14.40 \pm 0.06^{\mathrm{b}}$ & $12.87 \pm 0.09^{\mathrm{c}}$ & $13.23 \pm 0.15^{\mathrm{c}}$ & $18.20 \pm 0.06^{\mathrm{a}}$ \\
\hline \multicolumn{5}{|c|}{ Thinlip mullet } \\
\hline \\
\cline { 2 - 6 } & Initial & $\mathbf{C}$ & $\mathbf{L 1}$ & $\mathbf{L 2}$ & $\mathbf{L 3}$ \\
\hline Moisture & $77.83 \pm 0.32$ & $72.37 \pm 0.26^{\mathrm{a}}$ & $66.43 \pm 0.27^{\mathrm{b}}$ & $65.20 \pm 1.00^{\mathrm{c}}$ & $67.47 \pm 0.93^{\mathrm{b}}$ \\
\hline CP & $54.50 \pm 0.52$ & $62.40 \pm 0.49^{\mathrm{a}}$ & $52.40 \pm 0.06^{\mathrm{b}}$ & $53.47 \pm 0.49^{\mathrm{b}}$ & $52.23 \pm 0.23^{\mathrm{b}}$ \\
\hline EE & $12.17 \pm 0.09$ & $20.60 \pm 0.26^{\mathrm{d}}$ & $36.83 \pm 0.42^{\mathrm{a}}$ & $35.50 \pm 0.21^{\mathrm{b}}$ & $33.97 \pm 0.15^{\mathrm{c}}$ \\
\hline Ash & $32.40 \pm 0.52$ & $16.60 \pm 0.26^{\mathrm{a}}$ & $9.57 \pm 0.15^{\mathrm{c}}$ & $10.03 \pm 0.03^{\mathrm{c}}$ & $12.80 \pm 0.21^{\mathrm{b}}$ \\
\hline
\end{tabular}

The ether extract (EE) content of fish fed the $2 \%$ lemon peel diet was significantly lower than that measured in fish fed the $1 \%, 0.5 \%$ and control diets. Fish in the L3 treatment had the significantly $(\mathrm{p} \leq 0.05)$ highest ash content compared to that in fish in the L1, L2 and control treatments.

With respect to variations in the biochemical composition of thinlip mullet, there were significant differences $(p \leq 0.05)$ in the ash, protein, ether extract and moisture contents at the beginning and end of the feeding trial (Table 4). The final protein and ash contents of the fish fed the control diet were significantly higher than 
those of fish fed the $0.5 \%, 1 \%$ and $2 \%$ dietary lemon peel. Fish fed $0.5 \%$ lemon peel had a significantly higher ether extract content compared with fish fed the $1 \%$ and $2 \%$ lemon peel and the control diet.

The final mean biochemical blood parameters (creatinine, cholesterol, triglyceride, amylase, lipase and glucose) of Nile tilapia are presented in Table (5). Nile tilapia fed diet containing $2 \%$ lemon peel had the highest creatinine level compared to other groups. Non significant treatment differences were observed for lipase. The highest triglyceride, amylase and glucose contents were recorded in fish fed on $0.5 \%$ dietary lemon peel (L1)compared to other treatments and the control. The groups fed $2 \%$ dietary lemon peel had the lowest cholesterol, triglyceride, amylase and glucose contents. An increase in the lemon peel level from $0.5 \%$ to $1 \%$ induced a significant increase in cholesterol and a significant decrease in glucose.

Table 5: Biochemical blood parameters of Tilapiaand thinlip mullet at the end of the feeding trial.

\begin{tabular}{|l|l|l|l|l|}
\hline \multirow{2}{*}{} & \multicolumn{5}{|c|}{ Nile tilapia } \\
\cline { 2 - 5 } & C & L1 & L2 & L3 \\
\hline Creatinine & $0.40 \pm 0.01^{\mathrm{d}}$ & $0.50 \pm 0.02^{\mathrm{c}}$ & $0.60 \pm 0.01^{\mathrm{b}}$ & $0.70 \pm 0.01^{\mathrm{a}}$ \\
\hline Cholesterol & $101 \pm 2.08^{\mathrm{c}}$ & $117 \pm 2.52^{\mathrm{b}}$ & $157 \pm 3.79^{\mathrm{a}}$ & $81 \pm 1.15^{\mathrm{d}}$ \\
\hline Triglyceride & $115 \pm 2.08^{\mathrm{b}}$ & $134 \pm 3.06^{\mathrm{a}}$ & $94 \pm 2.08^{\mathrm{c}}$ & $75 \pm 1.53^{\mathrm{d}}$ \\
\hline Amylase & $231 \pm 3.46^{\mathrm{b}}$ & $473 \pm 5.13^{\mathrm{a}}$ & $208 \pm 3.21^{\mathrm{c}}$ & $201 \pm 2.89^{\mathrm{c}}$ \\
\hline Lipase & $3 \pm 0.12^{\mathrm{a}}$ & $3 \pm 0.15^{\mathrm{a}}$ & $3 \pm 0.06^{\mathrm{a}}$ & $3 \pm 0.10^{\mathrm{a}}$ \\
\hline Glucose & $102 \pm 3.21^{\mathrm{b}}$ & $130 \pm 2.08^{\mathrm{a}}$ & $94 \pm 1.73^{\mathrm{c}}$ & $42 \pm 0.58^{\mathrm{d}}$ \\
\hline & \multicolumn{4}{|c|}{ Thinlip mullet } \\
\cline { 2 - 6 } & $\mathbf{C}$ & $\mathbf{L 1}$ & $\mathbf{L 2}$ & $\mathbf{L 3}$ \\
\hline Creatinine & $0.70 \pm 0.01^{\mathrm{b}}$ & $0.70 \pm 0.01^{\mathrm{b}}$ & $0.70 \pm 0.01^{\mathrm{b}}$ & $1.40 \pm 0.06^{\mathrm{a}}$ \\
\hline Cholesterol & $117 \pm 1.73^{\mathrm{c}}$ & $117 \pm 2.31^{\mathrm{c}}$ & $142 \pm 2.65^{\mathrm{b}}$ & $157 \pm 2.89^{\mathrm{a}}$ \\
\hline Triglyceride & $135 \pm 2.89^{\mathrm{b}}$ & $135 \pm 3.46^{\mathrm{b}}$ & $272 \pm 4.04^{\mathrm{a}}$ & $273 \pm 4.93^{\mathrm{a}}$ \\
\hline Amylase & $25 \pm 1.53^{\mathrm{a}}$ & $25 \pm 0.51^{\mathrm{a}}$ & $15 \pm 0.21^{\mathrm{c}}$ & $19 \pm 0.32^{\mathrm{b}}$ \\
\hline Lipase & $2 \pm 0.06^{\mathrm{b}}$ & $2 \pm 0.06^{\mathrm{b}}$ & $2 \pm 0.12^{\mathrm{b}}$ & $4 \pm 0.12^{\mathrm{a}}$ \\
\hline Glucose & $60 \pm 1.53^{\mathrm{b}}$ & $89 \pm 1.73^{\mathrm{a}}$ & $55 \pm 1.15^{\mathrm{c}}$ & $49 \pm 1.15^{\mathrm{d}}$ \\
\hline
\end{tabular}

The results presented in Table (5) indicate significant changes in blood biochemical parameter levels in thinlip mullet. The significantly highest creatinine, cholesterol, triglyceride and lipase levelswere observed in response to diets containing $2 \%$ dietary lemon peel. The group fed $0.5 \%$ dietary lemon peel had significantly higher amylase and glucose values than the other groups.

\section{DISCUSSION}

The present study revealed that all tested levels of lemon peel (0.5, 1 and $2 \%)$ had a significant effect on the growth performance and total biomass of Nile tilapia and thinlip mullet. Feed acceptance by the fish was similar for all treatments, with no observed rejection. Limonene, the main component of the essential oils of lemon and grapefruit (Kirbaslar et al., 2006) has been reported to be effective against termites (Rainaetal., 2007), beetles (Tripathi et al., 2003) and fungi (Sharma and Tripathi 2006). Some studies have shown that a dietary supplement containing limonene and thymol had growth-promoting effects in poultry and some fish species (Ahmadifar et al., 2011, 2014; Dalkilicet al., 2015; Acaret al., 2015; Pérez-Sánchez et al.,2015; Shad et al., 2016; Zidanet al., 2016 and Ngugiet al., 2017). In our study, Nile tilapia fed $2 \%$ dietary lemon peel had the best FBW, WG and SGR values. We observed a significant increase in FBW, SGR and \% WG in thinlip mullet fed 0.5\% lemon peel compared to 1 and $2 \%$ lemon peel and the control group. Based on the results 
obtained in this study, it is concluded that the growth rate of biomass (Nile tilapia and thinlip mullet) was affected by the dietary lemon peel levels, and FW, WG and SGR increased significantly $(\mathrm{P} \leq 0.05)$ with increasing levels. In addition, the SGR, PER and total biomass of Nile tilapia and thinlip mullet fish fed $0.5,1$, and $2 \%$ dietary lemon peel increased significantly $(\mathrm{P} \leq 0.5)$ compared to the control group.The feed conversion ratio (FCR) of fish fed $0.5,1$, and $2 \%$ dietary lemon peel was significantly lower than that of fish fed the control diet. The current findings are consistent with results obtained for Mozambique tilapia, Oreochromismossambicus, when the essential oil extracted from Citrus sinensis peels was used in the diet (Acaret al., 2015). The improved growth performance and food conversion efficiency of fish fed different levels of dietary lemon peel may be attributed to the antimicrobial and antioxidant properties (Milos et al., 2000). Additionally, lemon peel may provide a cheap source of vitamin $\mathrm{C}$ that can be fortified into fish feed.

Creatinine is the end product of creatine metabolism and aids in muscle contraction. Most of the creatinine in the body is removed by the kidneys. Because of this, the levels of creatinine in the blood can indicate whether the kidneys are functioning properly (Walker et al., 1990). In the current study, Nile tilapia and thinlip mullet fed diets containing $2 \%$ lemon peel had significantly higher creatinine levels than fish in the other treatments, i.e., 0.7 and $1.4 \mathrm{mg} / \mathrm{dL}$ for Nile tilapia and thinlip mullet, respectively, followed by $1 \%$ dietary lemon peel $(0.6$ and $0.7 \mathrm{mg} / \mathrm{dL}$ for Nile tilapia and thinlip mullet, respectively) and $0.5 \%$ dietary lemon peel (0.5 and $0.7 \mathrm{mg} / \mathrm{dL}$ for Nile tilapia and thinlip mullet, respectively). Normal creatinine values range from 0.8 to $1.4 \mathrm{mg} / \mathrm{dL}$ (Solomon 2014). This means that all the recorded creatinine values for both, fish species were within the normal range, confirming the non-negative impacts of lemon peel on Nile tilapia and thinlip mullet.

Glucose is one of the most important energy substrates used by fish to cope with physiological stress; therefore, plasma glucoselevels have been used as an indicator of the stress response. Cortisol and glucose have been reported to increase in teleosts exposed to stress (Mommsen et al., 1999). In our study, one of the reasons that fish fed $2 \%$ lemon peel had the lowest glucose values may be because stress was avoided under high levels of (vitamin C) lemon peel.

In the present study,Nile tilapia fish fed $2 \%$ lemon peel had the lowest cholesterol and triglyceride levels; these values were significantly different from those measured in the other treatments. The highest cholesterol, triglyceride and lipase levels in thinlip mullet were observed in response to diets containing $0.5 \%$ lemon peel. The concentration of cholesterol in the blood can be influenced by nutrition, activity level, and hepatic activity and can be changed by the sexual cycle of fish. Triglycerides are the major lipids of adipose tissue and are the most important form of fat storage in the body. The concentration of triglycerides in the blood is influenced by the fat content in the diet and is therefore an important blood component to be evaluated in the use of new diets (Van der Boon et al., 1991).

Lipase secretion is characteristic of a highly organized intestine. Lipase is often analysed in combination with two other vital enzymes: protease and amylase. While lipase breaks down fats, protease digests proteins and amylase processes carbohydrates.

Levels of enzymatic activity measured by different authors are difficult to compare due to the use of different methods. Compared to other fish, lipase activity in juvenile sterlets and other sturgeon species is low (German et al., 2004; Furneet al., 2005). In this study, lipase and amylase activity differed significantly between the groups of thinlip mullet fed the different levels of dietary lemon peel. However, we 
did not observe significant effects of various levels of dietary lemon peel on lipase activity in Nile tilapia.

\section{CONCLUSION}

Based on the results obtained in this study, it can be concluded that the biomass growth rate of Nile tilapia and thinlip mullet is affected by different levels of dietary lemon peel. The addition of $2 \%$ dietary lemon peel had positive effects on the growth, feed utilization and total biomass of Nile tilapia, whereas the highest values for thinlip mullet were observed in the group treated with $0.5 \%$ lemon peel. The blood parameter results showed thatNile tilapia had the lowest triglyceride, amylase and glucose levels in response to $2 \%$ dietary lemon peel. By contrast, thinlip mullet fed $0.5 \%$ dietary lemon peel had the highest values of amylase and glucose.

\section{REFERENCES}

A.O.A.C. (2000). Association of Official Analytical Chemists official methods of analysis. Arlington, VA: Author.

Acar, U.; Kesbi, O.S.; Yilmaz, S.; Gultepe, N. and Turke, A. (2015). Evaluation of the effects of essential oil extracted from sweet orange peel, Citrus sinensis on growth rate of Mozambique tilapia, Oreochromis mossambicus, and possible disease resistance against Streptococcus iniae. Aquaculture, 437: 282-286.

Ahmadifar, E.; Falahatkar, B. and Akrami, R. (2011).Effects of dietary thymolcarvacrol on growth performance, hematological parameters and tissue composition of juvenile rainbow trout, Oncorhynchusmykiss. J. Appl. Ichthyol., 27: 1057-1060.

Ahmadifar, E.; Mansour, M.R.; Amirkolaie, A.K. and Rayeni, M.F. (2014). Growth efficiency, survival, and haematological changes in great sturgeon, Husohuso Linnaeus, 1758, juveniles fed on diets supplemented with different levels of thymol-carvacrol. Anim. Feed Sci. Technol., 198: 304308.

Baba, E.; Acar, U.; Onta, S.; Canan, K.; Osman, S. and Y1lmaz, S. (2016). Evaluation of Citrus limon peels essential oil on growth performance, immune response of Mozambique tilapia, Oreochromis mossambicus, challenged with Edwardsiellatarda, Aquaculture. 465, 13-18.

Cabello, F.C. (2006). Heavy use of prophylactic antibiotics in aquaculture: a growing problem for human and animal health and for the environment. In: Environmental microbiology., 8 (7): 1137-44.

Campbell, T. W. (2004). Clinical chemistry of fish and amphibians. -In: Thrall MA, Baker DC, Campbell TW, DeNicola D, Fettman MJ, LassenED, Rebar A. and Weiser G. (eds.), Veterinary Hematology and Clinical Chemistry. Lippincott Williams and Wilkins, Pennsylvania, p. 499-517.

Cowan, M.M. (1999). Plant products as antimicrobial agents.Clin.Microbiol. Rev., 12: 564-582.

Crawshaw, R. (2004). Co-product Feeds: Animal Feeds from the Food and Drinks Industries. Nothingham University Press.

Dalkilic, B.; Simsek, U.G.; Ciftci, M. and Baykalir, Y. (2015). Effect of dietary orange peel essential oil on physiological, biochemical and metabolic responses of Japanese quails as affected by early age thermal conditioning and fasting. Rev. Med. Vet., 166: 154-162. 
Esiobu, N.; Armenta, L. and Ike, J. (2002). Antibiotic resistance in soil and water environments. International Journal of Environmental Health Research, 12: 133-144

FAO, food and agriculture organization of the United Nations Rome (2016). The State of World Fisheries and Agriculture.

Friedewald, W. T., Levy, R. I. and Fredrickson, D. S. (1972). Estimation of the concentration of low-density lipoprotein cholesterol in plasma, without use of the preparative ultracentrifuge. Clinical Chemistry, 18: 499-502.

Furne, M.; Hidalgo, M.C.; Lopez, A.; Garcia-Gallego, M.; Morales, A.E.; Domezain, A.; Domezaine J. and Sanz, A. (2005). Digestive enzyme activities in Adriatic sturgeon Acipensernaccarii and rainbow trout, Oncorhynchusmykiss. A comparative study. Aquaculture, 250:391- 398.

German, D.P.; Horn, M.H. and Gawlicka, A. (2004). Digestive enzyme activities in herbivorous and carnivorous prickleback fishes (Teleostei: Sticchaeidae): ontogenetic, dietary, and phylogenetic effects. Physiol. Bioch. Zool., 77:789-804.

Henry, R. J. (1964). Clinical chemistry, New York and Row Publish.

Hixson, S.M. (2014). Fish Nutrition and Current Issues in Aquaculture: The Balance in Providing Safe and Nutritious Seafood, in an Environmentally Sustainable Manner. J Aquac Res Development, 5: 234

Kirbaslar, S. I.; Boz, I. and Kirbaslar, F. G. (2006).Composition of Turkish lemon and grapefruit peel oils. J. Esse. Oil Res., 18: 525-543.

Merchie, G.; Lavens, P. and Sorgeloos, P. (1997). Optimization of dietary Vitamin $\mathrm{C}$ in fish and crustacean larvae: a review. Aquaculture, 155: 165 - 181.

Milos M.; Mastelic J. and Jerkovic I. (2000). Chemical composition and antioxidant effect of glycosidically bound volatile compounds from oregano, Origanumvulgare L. ssp. Food Chemistry 71, 79-83.

Mommsen, T.P.; Vijayan,M.M. and Moon, T.W. (1999). Cortisol in teleosts: Dynamics, mechanisms of action and metabolic regulation. Rev. Fish Biol. Fish., 9: 211-268.

Ngugi, C.C.; Oyoo-Okoth, E. and Muchiri, M. (2017). Effects of dietary levels of essential oil (EO) extract from bitter lemon, Citrus limon, fruit peels on growth, biochemical, haemato-immunological parameters and disease resistance in juvenile, Labeovictorianus, fingerlings challenged with Aeromonas hydrophila. Aquac.Res., 48: 2253-2265.

Njoku, P. C.; Ayuk, A. A. and Okoye, C. V. (2011). Temperature Effects on Vitamin C Content in Citrus Fruits. Pakistan Journal of Nutrition, 10, 1168-1169

NRC, (1993). National Research Council. Nutrient Requirements of Fish. Washington, DC. National Academies Press.

Oluremi, O.I.A.; Ngi, J. and Andrew, I.A. (2007). Phytonutrients in citrus fruit peel meal and nutritional implication for livestock production. Livestock Research for Rural Development. Volume 19, Article 89.

Pérez-Sánchez, J., Benedito-Palos, L., Estensoro, I., Petropoulos, Y., CalduchGiner, J.A.; Browdy, C.L. and Sitjà-Bobadilla, A. (2015). Effects of dietary NEXT ENHANCE ${ }^{\circledR} 150$ on growth performance and expression of immune and intestinal integrity related genes in gilthead sea bream, Sparus aurata L., Fish Shellfish Immunol., 44: 117-128.

Raina, A.; Bland, J.; Doolittle, M.; Lax, A.; Boopathy, R. and Folkins, M. (2007). Effect of orange oil extract on the Formosan subterranean termite (Isoptera: Rhinotermitidae). J. Eco. Entomol., 100: 880-885. 
Shad, H.S.; Mazhari, M.; Esmaeilipour, O. and Khosravinia, H. (2016). Effects of thymol and carvacrol on productive performance, antioxidant enzyme activity and certain blood metabolites in heat stressed broilers. Iran. J. Appl. Anim. Sci., 6: 195-202.

Sharma, N. and Tripathi, A. (2006). Fungitoxicity of the essential oil of Citrus sinensis on post-harvest pathogens.World J. Micro.and Biotech., 22: 587593.

Solomon, John. (2014). Urea and Creatinine of ClariasGariepinus in three different commercial ponds. 1212. Nature and Science; (10) 12.

SPSS,(1997).Statistical package for the social sciences, Versions16, SPSS in Ch, ChiUSA.

Thomas, K. W. (1992). Conflict and conflict management: Reflections and update. Journal of Organizational Behavior, 13: 265-274.

Trinder, P. (1969). Determination of Glucose in Blood Using Glucose Oxidase with an Alternative Oxygen Acceptor. Clinical and biochemistry, 6: 24-27.

Tripathi, A. K.; Prajapati, V.; Khanuja, S. P. S. and Kumar, S. (2003). Effect of Dlimonene on three stored product beetles. J. Econ. Entomol., 96: 990-995.

Van der boon, J.; Van den Trillart, E.J.M. and Addink, A.D.E. (1991). The effect of cortisol administration on intermediary metabolism in teleost fish.Comparative Biochemistry and Physiology, Victoria, v.100, n.1, p.4753.

Walker, H.K.; Hall, W.D. and Hurst, J.W. (1990). Reference Clinical Methods: The History, Physical, and Laboratory Examinations. $3^{\text {rd }}$ edition, Boston: Butterworths; Chapter 193 BUN and Creatinine, Adrian O. Hosten.

Zidan, D.E.; Kahilo, K.A.; El-Far, A. and Sadek, K. (2016). Ginger, Zingiber officinale, and thymol dietary supplementation improve the growth performance, immunity and antioxidant status in broilers. Glob. Vet., 16: 530-538. 